DOI https://doi.org/10.30525/978-9934-26-180-0-32

\title{
YOUTH SPEECH IN INTERNET AND SHORT MESSAGE SERVICE
}

\author{
Rudenko M. Yu. \\ Candidate of Philological Sciences, \\ Assistant Professor at the Department of German and Slavonic Philology \\ Donbas State Pedagogical University \\ Sloviansk, Donetsk region, Ukraine
}

A significant changing of youth speech is currently observed. Relaxedness, emotionality, expression, constant refill by fresh slang words and expressions from different languages, especially English appear more in it. Youth language is under a serious influence of modern electronic informative technology. A written form of youth speech gets a wide spread in Internet, Short Message Service, that does not significantly differ from oral one. Speech of young men and women is rich in jargon words and phraseological units, including other languages. It is full of abbreviations, reductions, deformations; it is often used as a game, creation. While communicating, Indonesian young people, for example, the word " gue» (I am) is written " $g w »$, the word «buat» (for) is written «bwt», the word «nih» is written «ne», the word «see you» is written «cu», the word «aku» (I am) written «Q». etc. [7, p. 2].

Young men and women actively use their favourite communicative form Netspeak or Chatspeak, that includes peculiar features of both oral and written speech. Computer players use way of communication, named leetspeak or leet.

Written form of youth social dialects swiftly «captures» Internet: Web-portals, social nets, chats, blogs, forums. Especially popular are social nets, mastered by youth, both in global scale, and on the level of countries, regions, communities, groups of interests.

Written language of progamers, communicating in chats, is distinguished by a great amount of slang words. Simplified phrase in Leetspeak may be such: Me g0 gr4b s0Me k0ph33 (I am going to grab some coffee) [5, p. 271].

Young people use next main sources and means to form a written social dialectical vocabulary.

1. English borrowings or inheritance of word-forming processes of this language. Foreign language borrowing combines well with affixation: backup (En. backup) «to create reserve copies»; hamster (En. home page) «home page»; paga (En. page) «Internet page» [1, c. 920-921].

2. Metaphoric (metaphors and metonymies) is a powerful and productive source of lexical composition forming of written youth speech in the Internet 
space. For example, in Chinese Internet, to give expressiveness to foreign computer words in their phonetic borrowing, recording hieroglyphs are creatively used in such a way that in total they give a figurative funny meaning $[1$, c. 922].

3. Shortening and abbreviation. This source of word-formation is connected with boosting of messaging, language saving and game. A big amount of different types of shortenings are used in written speech of young people. Here are examples of students-linguists' vocabulary of Jakarta State University: $W O-$ «Wedding Organizer», EO - «Event Organizer», TM - «Technical Meeting», $F B-$ «Facebook», WA - «WhatsApp», OTW - «On The Way», $M C-\ll$ Master of Ceremony» [8, h. 70].

4. Errata, emoticons. Especially popular are so-called smiles - grimaces («muzzles»), combined from different punctual signs, that are used in chats, SMS, e-mails, etc. Deliberate distortion of the words of the native language are also often used. The similar has become traditional in Internet-communication, namely in Netspeak or Chatspeak in English, in Albany (Padonsky) - the variety of Internet-slang in Russian [3, c. 32, 100].

In comparison with everything mentioned above, the specific gravity of other sources of the formation of the lexical fund of written youth social dialects is less significant. In particular, means of word-formation are used: affix, metathesis, borrowing argotisms from the language of criminal elements, polysemy, antonomasia, synonymous or antonymic derivation, telescope, universalization (contraction), replacement of a word with a paronym, pun substitution, epenthesis, combination of word formation models.

Young people tend to use phraseological units, full of jargon words in written speech (start a mule "to deceive anyone", cut coupons "make money intensively", change shoes on the go "dramatically change your point of view, behavior, attitude towards someone").

Written form of slang is widely used by students. Their slang is intellectual, differs with active English using. Peculiar feature of student language is creation new unique slang words: kebangyngytyn, roke, tepar, TKP and others. Similar words are more often used in their circle, their meaning is not always available to outsiders [8, h. 62].

While communicating in Internet, gender character of slang appears. Written form of man slang in some cases differs from the girl one. Man slang often can be obscene. Woman one is more polite. It has no abuse, less obscene expressions. For example, at Indonesian youth humour site 1cak.com man slang is more logical, however it is sometimes vulgar and rude. Woman slang is more often soft, polite, consists of short phrases and sentences [6, p. 125]. Spanish girls often use the group of words with -i ending (besis, guapi, holi, okis) to 
make a conversation more tender and intimate. The majority of similar words are used in written speech [4, p. 149].

In written speech of boys and girls there are a lot of humorous expressions, that is peculiar for youth slang [4, p. 149]. For example, at Indonesian youth humour site, 1cak.com, admiration, creative praises are often met [6, p. 124-125]. Spanish youth use absurd rhymes in social nets: la polla con cebolla, la polla de Troya, estar más pedo que Alfredo, más a gusto que un arbusto, feliz como una perdiz, gay sin ley, ser un pipa de La Elipa, un truño como un puño [4, p. 148]. Ukrainian boys and girls have a creative approach to creation «smiles», Russian and Ukrainian comic expressions in Internet: «smack-smack», «to chat», «to like», «to twit» and many others [2, s. 55].

There are cases, when youth written speech is rude, vulgar. Poorly educated young people communicate so. For example: Me ha pegado to'l sobo. Esta hamburguesa está to buena. Está pa chope [4, p. 148]. Sometimes such form of communication is used as a joke. For example, young people at Indonesian humour site 1cak.com. sometimes use in communication jargon words and expressions for taunts, angry jokes, imitating criminal language. For example: Bitch Please, You Don't Say, Forever Alone, Go Home You Are Drunk, and Genius. Similar meme is given as an original photo or a picture with the corresponding sign [6, p. 124].

One of slang functions in written youth language is a secret communication. Such communication is resorted to representatives LGBT to differ from others, to hide the content of their conversations. For example: IYKWIM (if you know what I mean) [6, p. 124].

In the XXI youth sociolect becomes common, enters different spheres, pushes the boundaries of their application. As the spread of modern electronic information technologies expands (computer, Internet, Short Message Service) young people use written speech more actively, enriching it with new slang formations, making communication bright, juicy, picturesque, figurative, unusual for perception.

\section{References:}

1. Денисенко В. Н., Чжан Кэ. Заимствованное компьютерное и сетевое слово в русскоязычном и китайскоязычном коммуникативном пространстве Интернета. Вестник РУДН. 2018. Т. 9, № 4. С. 911-925.

2. Зернецкая О., Зернецкий П. Сквозные смыслы глобального пандискурса Интернета начала XXI века. Respectus philologicus. 2013. 23(28). S. 47-57. 
3. Столярчук О. В. Молодіжний сленг: функційнальний, лексико-семантичний та структурний аспекти : дис. ... канд. філол. наук : 10.02.15. Одеса, 2015. 224 с.

4. Aguilar E. C., Franco E. G. Voces y expresiones del argot juvenil madrileño actual. Círculo de Lingüística Aplicada a la Comunicatión. 2018. № 74. P. 149.

5. Coleman J. The Life of Slang. Oxford: Oxford University Press, 2012. $354 \mathrm{p}$.

6. Harared N. Slang created and used in 1cak.com site: a sociolinguistics study. Humaniora. 2018. Vol. 9, № 2. P. 119-127.

7. Noor R., Laksono A., Kawentar R. Cultural Development through Language Styles and Expression of Teenage Girls Identity in Indonesian Teen lit Novel Me Versus High Heels by Maria Ardelia. ICENIS. 2018. 73. P. 1-2.

8. Wulandari A. Penggunaan jargon oleh komunitas chatting WhatsApp grug. Transformatika. 2016. Vol. 12, № 2. H. 60-72.

DOI https://doi.org/10.30525/978-9934-26-180-0-33

\title{
НАУКОВА КАРТИНА СВІТУ ЯК ОСОБЛИВА ФОРМА СИСТЕМАТИЗАЦІЇ ЗНАНЬ
}

\author{
Товстенко В. P. \\ кандидат філологічних наук, \\ доцент кафедри бізнес-лінгвістики \\ Київський національний економічний університет \\ імені Вадима Гетьмана \\ м. Київ, Украӥна
}

Сукупність наукових знань, релігійних уявлень, естетичних, художніх та моральних цінностей певного соціуму, що проживає на певній території в конкретну історичну епоху - так визначають картину світу сучасні учені $[1$, c.70]. Думка про існування особливого мовного світогляду була сформульована видатним німецьким вченим В.Гумбольдтом ще на початку XIX ст. Він вважав, що людина стає людиною тільки через мову, у якій діють іiі творчі першосили, іiі глибинні можливості, отже, мова - це єдина духовна енергія народу. Мовна картина світу - це знання в мові та знання про мову, тобто мовні знання світу та знання про структуру мови. Мовну картину світу визначають як систему понять, характерну для 